\title{
Destruction of Knowledge: A Study of Journal Mutilation at a Large University Library
}

\section{Constantia Constantinou}

\begin{abstract}
Book and journal mutilation is a problem for libraries. The rising cost of replacing mutilated books and journals and the availability of out-of-print materials concerns many librarians. This paper examines one type of mutilation-the removal of pages from journal titles at the Elmer Holmes Bobst Library of New York University. The study reviews the related literature; it discusses the methodology of the descriptive study on journal mutilation at Bobst Library; it analyzes and interprets the results of the study, makes suggestions that could help reduce the problem, and proposes other topics for additional research.
\end{abstract}

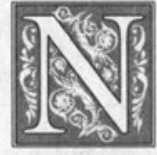

ot long ago, an e-mail message circulated among library collection staff which discussed the increasing problem of book and journal mutilation. The message outlining these issues read as follows:

This past term our library staff noticed an increase in the number of books and journal issues that are being damaged, e.g., pictures razor[ed] or torn out [and] entire contents removed with only the covers left on the shelves or in nearby garbage cans. So far, we have not been able to identify any particular subject area or collection that has been victimized more than another. In a time where our collections budget cannot keep pace with purchasing new publications, the cost of replacing older, heavily used material is a real concern. As well, several of the items are no longer in print and we are unable to replace them. . . . I would appreciate hearing any ideas for preventing, minimizing or coping with the situation. ${ }^{1}$

\section{Review of Related Literature}

Libraries realize that book and journal mutilation is a growing problem that simply does not go away. It is costly and disruptive for both libraries and library users. Book theft and mutilation are certainly not new developments of our time. Such acts can be traced as far back as 539 B.C. in Egypt when the Persian conquerors removed rolls of papyri from the library of Ramses II. Around 41 B.C. Anthony, emperor of Rome, raided the

Constantia Constantinou is a recent graduate of the Library and Information Studies Program at Queens College of The City University of New York and is a Bibliographic Searcher at the Elmer Holmes Bobst Library at New York University; e-mail: cnstntnc@is2.nyu.edu. 
Pergamon Library and gave all its contents to Cleopatra. During the Middle Ages, librarians chained library books in order to ensure that no one would steal them. Later, during the Renaissance, Pope Nicholas V issued a statute excommunicating anyone who did not return books belonging to the church. Unfortunately, the problem of mutilation still exists. Articles and case studies are continually written that explore the psychological and sociological aspects of the phenomenon of book and journal mutilation.

\section{The Motive}

It has been documented that motives to perform library violations are commonly attributed to sociological, psychological, and situational factors. ${ }^{2}$ Such library violations by users include:

- eating and drinking inside the library building,

- disfiguring text and illustrations,

- purposely misshelving items in order to deny access to them by other library users, and

- overborrowing library holdings.

The first step in attempting to understand the nature and the magnitude of the problem of book and journal mutilation is to recognize these actions as acts of disruption and vandalism.

Clyde Hendrick, a professor of psychology, and Marjorie Murfin, a reference librarian at Kent State University, approached the problem by studying their student population. ${ }^{3}$ The results of their survey showed that fourteen $(8.3 \%)$ of the 168 students who participated in the survey admitted mutilating journals. Their statistical data showed no significant differences in the attitudes of mutilators and nonmutilators.

A year later, Hendrick and Murfin published a study based on the interviews that they conducted with the three individuals who admitted having ripped out pages. ${ }^{4}$ The purpose of the interviews was to examine the reasons and motives that drove the students to mutilation. They discovered that hostility toward the library played a significant role in the mutilators' acts of vandalism. The misconception that unbound journals are cheaper than books also contributed to mutilation. In addition, the students' attitudes toward mutilation changed when they learned how difficult and costly it was to replace pages.

Academic pressure is a strong motive that can easily drive a person to misshelve books on purpose or to tear out pages. A student under pressure may hide the books and magazines in a particular area so that upon his or her return, he/she can locate the needed books or magazines quickly. This escalating problem of mutilation, as it relates to academic pressure, is also visible in professional schools. As one medical librarian stated, "The surgeons of tomorrow are practicing their technique on our magazines today." ${ }^{15}$

The results of Dana Weiss's study showed that academic pressure motivates students to mutilate books and journals, regardless of the quality of library services. ${ }^{6}$ Contrary to Hendrick and Murfin's findings, the Weiss study showed that the attitudes of students toward library services have no relation to book theft or journal mutilation. Weiss believes that people who steal and mutilate library materials do so for sociological as well as psychological reasons. She attributes mutilation to sociological factors such as the environment: "Because this study was done in an urban university library, it could be said that the 'toughness' of the city life causes the theft. However, I believe a case could be made for 'danger' on a rural college campus. ..."7

Conversely, Terri Pedersen showed that "situational circumstances" led students to mutilate and steal. ${ }^{8}$ Mutilating journals and stealing library books were not viewed as expressions of hostility toward the library or the university. Instead, such acts were viewed as inconsiderate acts toward the needs of their fellow students: 
Because Emporia is in a rural area, the "toughness of the city life" is not a cause of mutilation and theft. The fault does not appear to lie with the library being unfriendly, cold, and anonymous. Students did not view the theft and mutilation problem as an expression of hostility toward the institution but instead felt that their fellow students were selfish and did not consider the needs of others. ${ }^{9}$

Hendrick and Murfin suggest that libraries eliminate frustrating situations that can lead library users to act desperately. Theodore Hines, Thomas Atwood, and Carol Wall entertained the same theory. ${ }^{10,11}$ Their studies showed that broken copy machines, confusion, lack of time or easy access, uncaring library staff, lack of efficient directional signs, and unfamiliarity with the library environment and services generate frustration. Subsequently, anger builds up and library users take it out on library materials.

\section{Assessing Mutilation}

Carroll Varner suggests that by measuring journal mutilation, librarians are a step closer to preventing it. ${ }^{12}$ Mutilation can be detected in the circulation department, the bindery (the University of $\mathrm{Ne}$ braska at Omaha estimates that 50 percent of its mutilation is discovered from the bindery department), or by library users who report the incidents to the library staff. ${ }^{13,14}$ At the Pullen Library of Georgia State University, the Serials and Acquisitions unit is responsible for keeping track of journals with missing pages. ${ }^{15}$

Descriptive inventory is another highly methodical technique used to assess mutilation. Descriptive inventory is tedious and time-consuming but is one of the most systematic and reliable ways to assess the full extent of mutilation. The feat of conducting a descriptive inventory for the entire collection is almost impossible. Librarians prefer to examine designated areas of the collection, such as ref- erence collections. ${ }^{16}$ It is recommended, however, that if losses are above eight percent in any area of the collection, a full inventory must be taken. ${ }^{17}$

\section{The Elmer Bobst Study}

The purpose of this study was to identify the extent and rate of mutilation at the Elmer Holmes Bobst Library of New York University during the years 1990-1994. The study also attempted to identify titles and subject areas of the collection that are more vulnerable to mutilation than oth-

\section{Hendrick and Murfin suggest that libraries eliminate frustrating situations that can lead library users to act desperately.}

ers. In addition, the study investigated the possible relationship that exists between the availability of indexing and abstracting services on CD-ROM and the changes in the amount of journal mutilation.

The Elmer Holmes Bobst Library of New York University is located in Greenwich Village. It is New York University's main library. Bobst Library is the centerpiece of the New York University library system that includes four other specialized libraries which are located in the School of Law, the School of Medicine and Dentistry, the Institute of Fine Arts, and the Courant Institute of Mathematical Science. New York University is also a member of the Research Library Association of South Manhattan, a consortium that includes libraries such as the Cooper Union Library, the New School for Social Research Library, and the Parsons School of Design Library. The students of the consortium libraries share the same online public catalog, circulation system, and other library resources. Bobst Library is fully automated and houses approximately 2,505,182 book volumes, $2,361,025$ microfilm units, and 19,375 serial titles. ${ }^{18}$

\section{Methodology}

At the Bobst Library, mutilated items are 
identified in several ways: by the circulation department, the conservation laboratory, and the library users themselves. When the mutilated journal titles reach the collection services office, two employees assume responsibility for replacing the missing pages. The two employees examine each title using the method of page-by-page count and record all the pages that are missing. In addition to missing pages, they also record bibliographic information regarding the journal title in a log. The bibliographic profile contains information such as title, call number, year, volume, and issue number. When the count is completed, the information is transferred to an interlibrary loan (ILL) request and submitted to the Interlibrary Loan Office. The journal is then returned to the stacks with a note that the missing pages are on order. As the pages arrive from the Interlibrary Loan Office, the Collection Services employees retrieve the journal volumes from the stacks, inspect the ILL pages for completeness, photocopy the pages on acidfree paper (double-sided), and send them to the conservation lab to insert the pages in the bound volume. For the purpose of the study, the researcher collected all ILL requests submitted by Collection Services over the past five years (1990-1994). The researcher arranged 1,264 requests in chronological order, first by year and then by title.

\section{Findings and Analysis}

The first group of data corresponding to the year 1990 revealed the following: 102 titles suffered some type of mutilation, 142 volumes of the journal titles suffered damage, $4,370(20.8 \%)$ pages were torn out, and 204 incidents of mutilation occurred. During 1991, the figures had dropped significantly: mutilation affected fifty-eight titles and one hundred volumes, 2,410 (11.5\%) pages were torn out, and the incidents of mutilation dropped to 152. By 1992, fifty-five journal titles suffered mutilation, eighty-nine volumes were mutilated, 2,038 $(9.6 \%)$ pages were ripped out, and 109 incidents of mutilation occurred. In 1993, the numbers in volumes, pages, and incidents suddenly increased: 102 titles suffered mutilation, 218 volumes were mutilated, 6,987 $(33.1 \%)$ pages were torn out, and 545 incidents of mutilation occurred. In 1994 (January-October) the numbers slightly decreased from the year before with eighty-four titles suffering mutilation. In addition, 167 volumes were mutilated, $5,256(25 \%)$ pages were torn out, and 254 incidents of mutilation occurred.

Table 1 demonstrates and summarizes the mutilation history of the Bobst Library at New York University for 1990-1994. It indicates the number of titles mutilated per year, as well as the number of volumes, pages, and incidents (number of times that each title had to be requested from the Interlibrary Loan Office). Table 1 indicates clearly that the heaviest mutilation occurred during 1993 since more titles, volumes, and pages were mutilated in 1993 than any other year. The rate of mutilation was also the highest with 545 incidents.

\section{Possible Reasons for the Increase in Mutilation during 1993}

The heaviest mutilation in terms of number of volumes, pages, and incidents occurred within the call number ranges GV1580-GV1787 (Recreation, Leisure), HQ75 (Social Science: Sociology), and PN2 (English, American, and European Literature). The call number range GV1580-GV1787 includes journals related to the Dance Collection. Titles such as Dance World, L'Avant Scène Ballet Danse, Dance and Dancers, Dance Chronicle, Dance Life, Dancing Times, Ballet News, and Ballett International endured extensive mutilation.

Among the aforementioned titles, the most heavily mutilated was Ballett International. Ten of its volumes suffered mutilation during seventy-four incidents, and a total of 1,027 pages were torn out. 


\begin{tabular}{|lcclc|}
\hline \multicolumn{5}{c|}{ TABLE 1 } \\
\hline \hline Year & $\begin{array}{l}\text { Number of } \\
\text { titles and \% }\end{array}$ & $\begin{array}{l}\text { Number of } \\
\text { volumes and } \%\end{array}$ & $\begin{array}{c}\text { Number of } \\
\text { pages and \% }\end{array}$ & $\begin{array}{c}\text { Number of } \\
\text { incidents and } \%\end{array}$ \\
\hline 1990 & $102(25.4 \%)$ & $142(20 \%)$ & $4,370(20.8 \%)$ & $204(16.2 \%)$ \\
1991 & $58(14.5 \%)$ & $100(14 \%)$ & $2,410(11.5 \%)$ & $152(12 \%)$ \\
1992 & $55(13.7 \%)$ & $89(12.5 \%)$ & $2,038(9.6 \%)$ & $109(8.6 \%)$ \\
1993 & $102(25.4 \%)$ & $218(30.5 \%)$ & $6,987(33.1 \%)$ & $545(43.1 \%)$ \\
1994 & $84(21 \%)$ & $167(23 \%)$ & $5,256(25 \%)$ & $254(20.1 \%)$ \\
\hline Total & 401 & 716 & 21,061 & 1,264 \\
\hline
\end{tabular}

Ballett International is a German publication that consists of both articles and illustrations. The type of mutilation regarding Ballett International involved tearing out illustrations and articles.

Dance and Dancers, Dancing Times, and Ballet News formed the next group to fall into the category of heavy mutilation. In each title, mutilation occurred in approximately ten volumes and affected 720 pages from each publication. The type of mutilation was similar in all dance titles; vandals tore out illustrations, articles, and advertisements indiscriminately.

\section{Observations and Interpretations}

New York University has a large department in performing arts that supports both the undergraduate and graduate programs in dance, theater, and performing arts. Consequently, the dance collection is used heavily by a large population of students. However, close examination of the physical volumes revealed that an individual or a small group of individuals caused the mutilation of the dance collection. This speculation is based on the following findings: 1) the mutilation occurred within a period of six months, which is a very short time for a mutilation of this magnitude to take place unless someone systematically and continuously mutilated the journals; and 2) pages were simply torn out (including articles, advertisements, and illustrations) and left either inside the journal or some- where on the shelves close by, awaiting discovery.

The second category of journals that suffered extensive mutilation consisted of two titles both in the field of Social Science, specifically in sociology, family, and marriage (HQ75). The mutilated titles were Christopher Street and Journal of Homosexuality. The Journal of Homosexuality is a scholarly journal that contains only articles, as opposed to Christopher Street, which is a popular, highly illustrated journal that deals with homosexual issues. Eleven volumes from the Journal of $\mathrm{Ho}$ mosexuality suffered mutilation and 170 pages were torn out. This type of mutilation consisted of entire articles being ripped out. Eleven volumes from Christopher Street suffered mutilation, with 488 pages being torn out. The pattern of mutilation showed that the majority of the pages torn out contained illustrations,

\section{However, close examination of the physical volumes revealed that an individual or a small group of individuals caused the mutilation of the dance collection.}

including the front covers of magazine issues. In addition, the researcher discovered defaced pages with ink writings.

During the summer of 1993, New York University offered a class through the program of Social Work that required writing papers based on extensive read- 
ings from the Journal of Homosexuality. At the same time, many students complained to librarians at the Social Science reference desk after discovering entire articles torn out of the Journal of Homosexuality. It might have been possible that their fellow classmates mutilated the journal or it might just have been a coincidence that they discovered the mutilation during the semester that they were enrolled in the course. In the case of the Journal of Homosexuality, the library purchased a copy of the title on microform and retained the print version on the shelf.

As for Christopher Street, two types of mutilation occurred. The first type of mutilation involved tearing out pages and covers whose content consisted mostly of illustrations and photographs. The second type of mutilation involved alternating the text and illustrations. Apparently, individual(s) decided to deface some of the journal's pages as a way of expressing his or her personal beliefs on homosexuality. The person(s) quoted passages from Christian books condemning homosexuality. Even though the defaced pages were not ripped out, the collection services staff had to replace them with photocopied ones.

\section{Mutilation by Subject Classification}

In order to analyze the data by classification categories, the researcher divided titles into subject categories using the Library of Congress Classification Schedules as a consulting tool, and grouped all mutilated titles into twenty-four classification categories. Table 2 indicates the Library of Congress Classification Number (LCCN) for each subject category, the different classification categories that were affected by mutilation (in certain subject categories where mutilation was heavily detected, the categories break down to smaller subdivisions), the number of volumes affected by mutilation for each of the classification categories, the percentage of the mutilated volumes for each of the subject areas, the number of mutilated pages per category, the percentage of page mutilation, the number of incidents per subject category, and the corresponding percentages.

Table 2 lists the affected subject categories. The five most affected categories were History, Recreation and Leisure, Social Science and Economics, Social Science and Sociology, and General English, American and European Literature. The area of History (D) suffered the heaviest mutilation in terms of number of pages, with 3,918 pages torn out and 138 ILL requests submitted during the past five years (1990-1994). The researcher detected a significant portion of the mutilation in this area, specifically in the titles Orbis, Past and Present and Journal of Contemporary History.

In the area of Recreation and Leisure (GR-GV) 3,790 pages were torn out and 288 incidents of mutilation occurred. As discussed earlier, the titles that suffered most of the mutilation in the Dance Collection were Ballett International, Dance and Dancers, Dancing Time, and Ballet News. Social Science and Economics ( $\mathrm{H}-\mathrm{HJ})$ contained 3,311 mutilated pages with 192 incidents of mutilation. Damaged titles that contributed to this area's mutilation were the Journal of Public Economics, Politics and Society, and Review of Economic Studies. Social Science and Sociology (HM-HX) was the fourth highest affected area with 2,445 mutilated pages and 197 incidents of mutilation. Christopher Street, Journal of Homosexuality, and Children Today sustained the most mutilation in this category. The fifth group of journals that falls into the heavy mutilation category is the classification area of General English, American and European Literature (PN-PS). The researcher discovered 1,666 mutilated pages and counted eightyseven incidents of mutilation. Among the titles most affected were Boundry 2, Literature Film Quarterly, and Wide Angle.

\section{Rate of Mutilation}

As seen in the analysis of table 2, the 


\begin{tabular}{|c|c|c|c|c|c|c|c|}
\hline \multicolumn{8}{|c|}{$\begin{array}{c}\text { TABLE 2 } \\
\text { Subject Categories, 1990-1994 }\end{array}$} \\
\hline LCCN & Subject & Volumes & $\%$ of All Vol. & Pages & $\%$ of All Pages & Incidents & $\%$ of All Incidents \\
\hline A & General Works & 10 & 1.40 & 316 & 1.50 & 11 & 0.87 \\
\hline B-BF & Philosophy/Psychology & 47 & 6.56 & 1,014 & 4.81 & 51 & 4.03 \\
\hline BJ & Psychology-Ethics & 1 & 0.14 & 25 & 0.12 & 1 & 0.08 \\
\hline BL & Religion & 9 & 1.26 & 108 & 0.51 & 13 & 1.03 \\
\hline C & Auxiliary Science & 5 & 0.70 & 115 & 0.55 & 5 & 0.40 \\
\hline D & History & 81 & 11.31 & 3,918 & 18.60 & 138 & 10.92 \\
\hline E-F & History (American) & 29 & 4.05 & 647 & 3.07 & 35 & 2.77 \\
\hline G-GR & Geography-Anthropology & 30 & 4.19 & 439 & 2.08 & 27 & 2.14 \\
\hline GR-GV & Recreation, Leisure & 73 & 10.20 & 3,790 & 18.00 & 288 & 22.78 \\
\hline $\mathrm{H}-\mathrm{HJ}$ & Social Science: Economic & 128 & 17.88 & 3,311 & 15.72 & 192 & 15.19 \\
\hline HM-HX & Social Science: Sociology & 73 & 10.20 & 2,445 & 11.61 & 197 & 15.59 \\
\hline $\mathrm{J}$ & Political Science & 13 & 1.82 & 335 & 1.59 & 19 & 1.50 \\
\hline L & Education & 26 & 3.63 & 712 & 3.38 & 34 & 2.69 \\
\hline M & Music & 17 & 2.37 & 335 & 1.59 & 22 & 1.74 \\
\hline $\mathrm{N}$ & Fine Arts & 14 & 1.96 & 131 & 0.62 & 17 & 1.34 \\
\hline P-PA & Gen. Philology \& Linguist. & 19 & 2.65 & 471 & 2.24 & 26 & 2.06 \\
\hline PB-PJ & Modern Euro. \& Orient. Lang. & 10 & 1.40 & 212 & 1.01 & 12 & 0.95 \\
\hline PN-PS & General Literature & 68 & 9.50 & 1,666 & 7.91 & 87 & 6.88 \\
\hline Q & Science & 6 & 0.84 & 136 & 0.65 & 7 & 0.55 \\
\hline $\mathrm{R}$ & Medicine & 34 & 4.75 & 766 & 3.64 & 41 & 3.24 \\
\hline $\mathrm{T}$ & Technology & 17 & 2.37 & 115 & 0.55 & 35 & 2.77 \\
\hline $\mathrm{U}$ & Military Science & 1 & 0.14 & 11 & 0.05 & 1 & 0.08 \\
\hline V & Naval Science & 1 & 0.14 & 7 & 0.03 & 1 & 0.08 \\
\hline$\underline{Z}$ & Bibliography, Library Science & 4 & 0.56 & 35 & 0.17 & 4 & 0.32 \\
\hline Total & & 716 & & 21,060 & & 1,264 & \\
\hline
\end{tabular}


mutilation of pages is not always analogous to the rate of mutilation incidents. Table 3 lists the top four classification categories based on the number of incidents arranged in descending order. Even though the category of Recreation and Leisure (GR-GV) ranked second in terms of number of mutilated pages $(3,790)$, it still had the highest rate of mutilation incidents with 22.78 percent. The Social Science and Sociology (HM-HX) category ranked fourth in terms of smallest number of mutilated pages, but in terms of the rate of mutilation, it ranked second with 15.59 percent. The number of mutilated pages paralleled the rate of mutilation in the area of Social Science and Economics. In terms of pages and incidents, this category ranked third with 15.72 percent of mutilated pages and 15.19 percent of incidents. The last category, History (D), ranked fourth in number of incidents. Even though History had the highest number of mutilated pages $(3,918)$, the rate of mutilation was only 10.92 percent.

Possible reasons for this high rate of mutilation in the categories of Recreation and Leisure (GR-GV) and Sociology (HM$\mathrm{HX}$ ) may stem from the nature of some of these journal titles. Titles from the GRGV classification category, such as Ballett International, Dance and Dancers, Dancing Times, Ballet News, and Christopher Street (HQ) are highly illustrated journals. Illus- trations, especially color ones, turn titles into prime targets for mutilation.

As stated above, the area of History suffered the heaviest mutilation with 3,918 pages missing, even though the rate of incidents (138) is the lowest. This type of asymmetry can be attributed to mutilation of titles such as Orbis (1,740 pages missing), Journal of Contemporary History (618 pages missing), and New York History (177 pages missing) that contain lengthy articles and no illustrations. Thus the person(s) who mutilated these journals ripped out long articles, which increased the number of pages torn out.

\section{Relationship Between the Availability of CD-ROM Indexing Services and the Changes in Mutilation}

In order to find out if a relationship between the availability of indexing services on CD-ROM databases and the changes in the amount of mutilation at the Elmer Holmes Bobst Library exists, the researcher organized the data in the following manner: titles with 500 or more missing pages (Christopher Street included with 488 missing pages) and organized the raw data in a table. In this way, the researcher could establish whether highly mutilated titles are affected by title availability on a CD-ROM database (see table 4). Table 4 indicates the classification number of the mutilated title, the journal title, the number of missing pages for each

\begin{tabular}{|c|c|c|c|c|c|}
\hline \multicolumn{6}{|c|}{$\begin{array}{c}\text { TABLE } 3 \\
\text { Rate of Mutilation }\end{array}$} \\
\hline $\mathrm{LCCN}$ & Subject & Pages & $\begin{array}{c}\% \text { of } \\
\text { pages }\end{array}$ & Incidents & $\begin{array}{c}\% \text { of } \\
\text { incidents }\end{array}$ \\
\hline GR-GV & $\begin{array}{l}\text { Recreation } \\
\text { Leisure }\end{array}$ & 3,790 & 18.00 & 288 & 22.78 \\
\hline HM-HX & $\begin{array}{l}\text { Social Science: } \\
\text { Sociology }\end{array}$ & 2,445 & 11.61 & 197 & 15.59 \\
\hline $\mathrm{H}-\mathrm{HJ}$ & $\begin{array}{l}\text { Social Science: } \\
\text { Economics }\end{array}$ & 3,311 & 15.72 & 192 & 15.19 \\
\hline D & History & 3,918 & 18.60 & 138 & 10.92 \\
\hline
\end{tabular}


of the titles, the CD-ROM indexing database for each of the corresponding titles available at Bobst, the starting year of the CD-ROM database coverage for each of the titles, the year that each of the CDROM databases became available to Bobst Library users, the year in which mutilation occurred, and the number of missing pages from the volumes whose years were covered by a CD-ROM database.

\section{Analysis and Interpretation}

As seen in table 4, three out of the eight journals are indexed by a CD-ROM database available to Bobst Library users. These titles are Orbis (ranked first in terms of number of pages missing with 1,740), World Politics (ranked third with 1,010 missing pages), and Journal of Contemporary History (ranked seventh with 618 missing pages). The other five journalsBallett International, Dance and Dancers, Dancing Times, Ballet News, and Christopher Street-were either not indexed by a CD-ROM database or, if they were, the database was not available at the Bobst Library at the time that the library staff detected the mutilation.

In the case of Orbis, which is the most heavily mutilated title, the library staff discovered the mutilation in 1994, a year when Periodical Abstracts, Predicasts, and PAIS were available on CD-ROM. The 453 missing pages were detected in volumes from 1976 to 1982 . Periodical Abstracts and Predicasts began their CD-ROM coverage in 1989 and 1991, respectively. The only CD-ROM indexing source that covers mutilation of volumes from 1976 to 1982 is PAIS, which began its coverage in 1976. It is possible that the 453 missing pages from Orbis (out of a total number of 1,740 pages) is a result of the availability of the CD-ROM indexing database. In all the other titles, the library staff discovered the mutilation in the volumes not included in the years the CD-ROM databases cover. It is clearly shown in table 4 that no relationship exists between the availability of indexing and abstracting services on CD-
ROM databases and the changes in the amount of mutilation at the Elmer Holmes Bobst Library.

\section{Conclusions and Recommendations}

Frances Meals said that it is a real challenge for libraries to be able to give the user the best possible service. Such service involves preserving the collection so that what the user wants is always there and is conveniently available for use for as long as he/she needs it. ${ }^{19} \mathrm{It}$ is clear that journal mutilation affects students' education. Students cannot use the library's resources to their fullest because they cannot find articles in mutilated journals. They often have to wait for days to get replacement pages through ILL services.

The findings of this case study indicate that the problem of journal mutilation is disruptive to the library and its users. Although book and journal mutilation continues to be a problem, it is not an incurable one. In fact, public campaigns have proven effective in combating book and journal mutilation. Such campaigns emphasize educating users on the difficulties of obtaining replacements. These antimutilation campaigns also can involve:

- Posting signs with the warning that mutilation is a punishable crime.

- Creating awareness of the problem by utilizing the campus newspaper and media outlets.

- Providing an adequate number of photocopiers, change machines, and vendor card machines to dissuade users from mutilation.

- Announcing the closing times in order to give students a chance to complete their photocopying.

- Encouraging faculty to place an adequate number of required readings on reserve, especially during exam periods.

- Encouraging users to report immediately any missing pages from the stacks.

- Involving librarians more in maintaining and reviewing the physical condition of titles. 


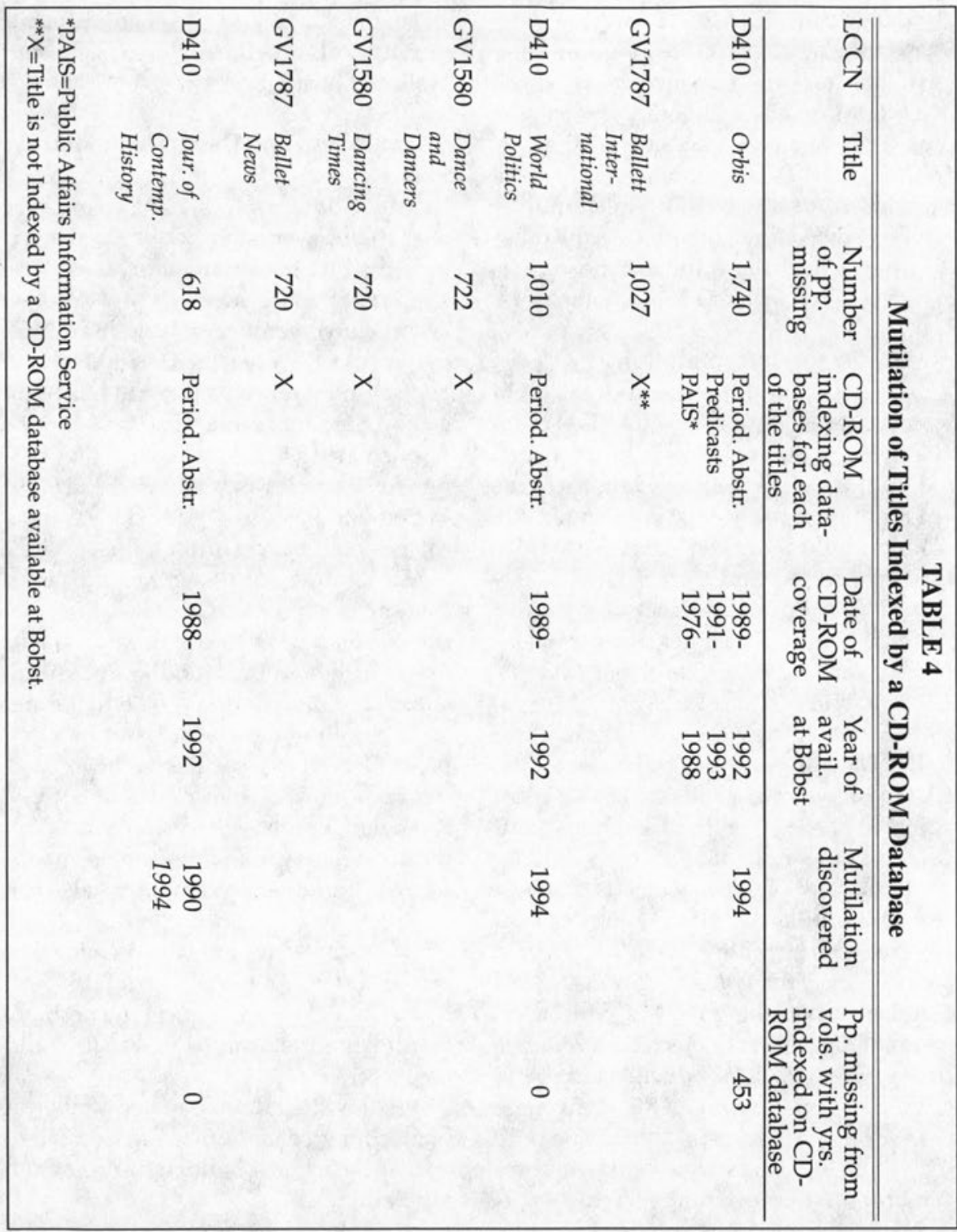

\section{Additional Areas of Study}

In an attempt to gain better understanding of the problem of book and journal mutilation, researchers suggest studying additional areas. For example, very few studies report on the cost associated with mutilation. Therefore, there exists a need for researching and documenting such costs that can reveal further the extent and magnitude of the problem. Whether it involves in-house treatment, commercial binding, and ILL service expenses, the cost of replacing articles and out-of-print monographs is very high.

Another area to investigate is the extent of mutilation of monographs. This investigation can be taken a step further by comparing mutilation of monographs with mutilation of journals. Such an investigation could elicit interesting results 
if it found a correlation between mutilation in the monograph collection and the journal collection in similar subject areas.

A study needs to be undertaken that examines the areas of a library's collection that were subject to budgetary cuts, and then investigates mutilation to see if a relationship exists between such cuts and the amount of mutilation. Research has shown that the problem of book and journal mutilation does not have a permanent solution, but ignoring the issue is certainly not the answer. For the sake of knowledge, truth, and the people who seek them, the conscientious librarian has to make a choice: he or she can chose to work in silence or to protect the library

collection from mutilators, thieves, and vandals by confronting the problem of mutilation and actively reacting to it.

\section{Notes}

1. Susan Bolton, "Dealing with Increase in Willful Destruction," Library Collection Development List, no. 284, COLLDVL@USVM.BITNET (Jan. 1994).

2. Sharon Mast, "Ripping Off and Ripping Out: Book Theft and Mutilation from Academic Libraries," Library \& Archival Security 5 (winter 1983): 39.

3. Clyde Hendrick and Marjorie E. Murfin, "Project Library Ripoff: A Study of Periodical Mutilation in a University Library," College \& Research Libraries 35 (Nov. 1974): 402-11.

4. - , "Ripoffs Tell Their Story: Interviews with Mutilators in a University Library," Journal of Academic Librarianship 1 (May 1975): 8-12

5. Carroll Varner, "The Causes, Measurement, and Prevention of Journal Mutilation in an Academic Library," ERIC Document Reproduction Service, no. ED 234817 (1983): 77.

6. Dana Weiss, "Book Theft and Book Mutilation in a Large University Library," College \& Research Libraries 42 (July 1981): 345.

7. Ibid.

8. Terri Petersen, "Theft and Mutilation of Library Materials," College \& Research Libraries 51 (Mar. 1990): 128

9. Ibid.

10. Theodore Hines, "Theft, Mutilation and the Loss-to-Use Ratio," Library Security Newsletter 1, no. 3 (May/June 1975): 1-4.

11. Thomas Atwood and Carol Wall, "A Case Study of Periodical Mutilation in a University Serials Collection," Library \& Archival Security 10, no. 1 (1990): 35-41.

12. Carroll Varner, "The Causes, Measurement, and Prevention of Journal Mutilation," 78.

13. Ibid.

14. Carroll Varner, "Journal Mutilation in Academic Libraries," Library \& Archival Security 5 (winter 1983): 20

15. Joan M. Luke, "The Mutilation of Periodicals in a Mid-Size University Library," The Serials Librarian 20 (1991): 95-109.

16. Jeannette Bobeen, "Mutilation of Library Resources: Containing a Study of Mutilation of the Reference Collection of the Undergraduate Library, Ellis Library, University of MissouriColumbia" (M.A Thesis, Department of Library Science, University of Missouri-Columbia, 1974).

17. Carol Wall, "Inventory What You Might Expect to Be Missing," Library \& Archival Security 7 (summer 1985): 27.

18. Elmer Holmes Bobst Library, New York University Libraries Fact Sheet (New York: New York University, fall 1993).

19. Frances Meals and W. J. Johnson, "We Choose Microfilm," College \& Research Libraries 21 (Jan. 1973): 223-26. 


\section{GREENWOOD PRESS Literature}

\section{Third World}

\section{Women's Literatures}

A Dictionary and Guide to Materials in English By Barbara Fister

Serves as a "companion" to Third World women's literatures in English and in English translation by presenting entries on works, writers, and themes. Entries are chosen to present a balance of wellknown writers and emerging ones, contemporary as well as historical writers, and representative selections of genres, literary styles, and themes.

Greenwood Press. 1995. 408 pages.

0-313-28988-3. \$75.00

\section{A Herman Melville Encyclopedia}

\section{By Robert L. Gale}

A comprehensive guide to Melville's life and work. Included are hundreds of entries for his writings, characters, family members, friends, and acquaintances. The volume identifies characters from Melville's works, and entries on the most important topics include bibliographies.

Greenwood Press. 1995. 560 pages.

0-313-29011-3. \$79.50

\section{Indigenous Literature of Oceania}

\section{A Survey of Criticism and Interpretation \\ By Nicholas J. Goetzfridt \\ Bibliographies and Indexes in}

World Literature, No. 47

Choice 1993 Outstanding Academic Book List

Published under the Auspices

of the Guam Humanities Council

Foreword By Vilsoni Hereniko

"Complementing the author's earlier Indigenous Navigation and Voyaging in the Pacific this book extends coverage to international reactions to the literature written by Oceanic authors. The bibliography and the extensive indexes are valuable in themselves. For all libraries interested in this often neglected part of world literature."

Choice

Greenwood Press. 1995. 368 pages.

0-313-29173-X. $\$ 75.00$

\section{Reference}

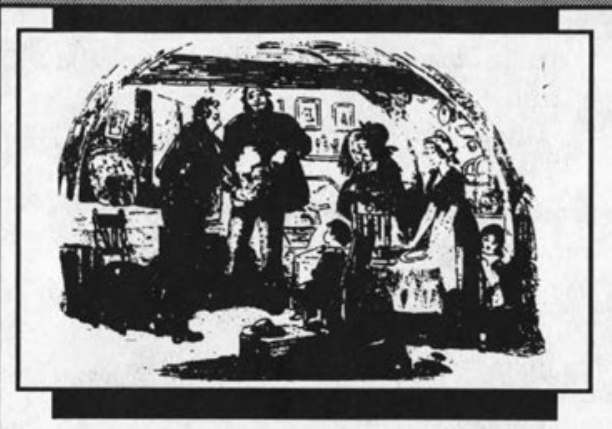

\section{Everyone in Dickens}

Compiled and edited By George Newlin

"... an amazing achievement and one that will be of huge benefit to all students of Dickens. .."

Michael Slater University of London author of Dickens and Women co-editor of The Dickens Index

'Now, like an expert surveyor of Dickens' universe, George Newlin has for the first time organized and charted almost its every feature. Where there were black holes and missing stars, there is now light. Almost every conceivable item of fact bearing in his people is contained within Everyone in Dickens. ... Newlin has created a reference work that supplants every other work that has attempted to be a Dickens encyclopedia, dictionary, or guide. . ."

Fred Kaplan, Distinguished Professor City University of New York author of Dickens: A Biography

Four hundred seventy-one titles are dealt with in Everyone in Dickens, a three-volume reference set including: 5,200 individual character entries in Volumes I and II; 14,600 different figures reflected in Volume III; 293 illustrations associated with the earliest issuances of the works; and a series of 12 one-of-a-kind indexes covering characters by name, characters by family relationship, all historical persons mentioned, and much more.

Greenwood Press. 1995. 2568 pages.

Three-volume Set. 0-313-295808.\$275.00

illustrations, indexes, time chart.

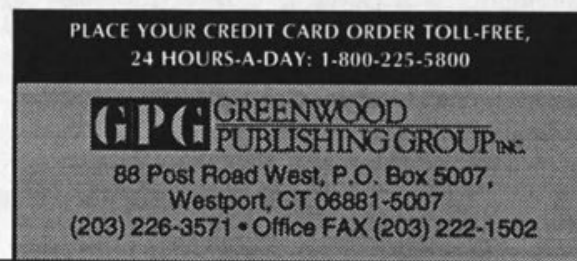

